\title{
Constructed Languages of Hildegard of Bingen and Suzzette Haden Elgin. Female Empowerment through Language?
}

\begin{abstract}
Summary
Since constructed languages have recently been brought into focus by their prominent presence in film and television production, they have also become more attractive for academic research: several compendia, monographs, and articles have been published on the topic of classification and analysis of conlangs. Glossopoeia of Hildegard of Bingen and Suzette Haden Elgin is unique among the plethora of constructed languages in several aspects: elusive classification, unusual lexical focus, high level of completeness, and female authorship. The article investigates possible classifications of lingua ignota and Láadan, and their grammatical, lexical, and phonological characteristics. It also aims to establish the success of the languages measured against their goal stated or implied by their inventresses and the objectives generally set for constructed languages.
\end{abstract}

Keywords: glossopoeia, constructed language, invented language, imaginary language, artistic language, Hildegard of Bingen, Suzette Haden Elgin, lingua ignota, Láadan

\section{Introduction}

Constructed languages are usually created (or initiated, as in the case of Esperanto) by a single individual interested in providing a means of communication and motivated by "dissatisfaction with the current linguistic state of affairs" (Adams 2011, chapter 8). Hildegard of Bingen and Suzette Haden Elgin were two female language creators who strived, through their glossopoeic acts, to offer such means to their communities: a medieval Benedictine convent and a twentiethcentury international community of women seeking a way to communicate outside the constraints of languages controlled by men. Higley and Okrent emphasise the homogeneity of the community of language creators: virtually all creators of fully developed constructed languages are male (Higley 2007, p. 8; Okrent 2010, p. 99), which establishes Hildegard and Elgin as two significant exceptions offering a uniquely female perspective.

1 https://orcid.org/0000-0002-7701-9653. 
A language which, in opposition to natural languages, is a conscious creation of an individual or a group eludes taxonomy. Albani and Buonarroti choose the term 'lingua immaginaria" (2011, p. 7), Conley and Cain prefer 'artificial' (2006, p. xxi), Eco uses 'constructed artificially' (1995, p. 2), Okrent 'invented' (2010, p. 10), Peterson 'constructed' and 'conlang' (2015, pp. 7, 11), Wojan 'skonstruowany' - 'constructed' (2016, p. 123). What appears to be most commonly used is the term 'constructed language', or 'conlang' in short, as it includes all types of non-natural languages. The second issue is the division of conlangs into categories precise enough for the identification and description of such languages. To define the constructed language as a phenomenon, and to categorise it is to scrutinise the motives behind its creation.

Artistic languages, or artlangs, serving an exclusively aesthetic purpose, appear in novels, films and tv series; auxlangs, auxiliary languages intended as a universal means of communication not dependent on culture or politics, are usually limited to the virtual reality and self-published manuals. Artlangs often remain incomplete (with the historic exception of Tolkien's glossopoeic achievements in The Lord of the Rings), or even more speculative than real, since the narratives purporting to use them are actually rendered in the natural language native to the author and only produce limited utterances in order to achieve the aesthetic effect mentioned above. The desired outcome may be an impression of otherness, a specific aural effect, such as harsh, 'barbaricsounding' tones or soft, 'melodic' sounds, an atmosphere of secrecy or danger etc. Stockwell argues most artlangs are a form of neography, existing only in the written form (2006, p. 7), although this assumption excludes those languages constructed for cinema and television, of which Klingon is the most often cited example.

Auxlangs, on the other hand, are designed for communication, whether to offer a universal, easy-to-learn language drawing from existing resources, such as Volapük or Esperanto, or more logical and unambiguous, if somewhat more difficult (or almost entirely impossible to learn), languages such as Loglan or Lojban. The purpose of both art- and auxlangs is often encoded in their grammar: limited, simplified and regular grammatical rules point to the prevalence of linguistic utility over an aesthetic value, while intricate, often irregular linguistic embellishments, conversely, signal sole aesthetic purposes (Barnes, Van Heerden 2006, p. 114).

Other categories of constructed languages include glossolalia (a nonlanguage spoken in religious trance), logical languages invented mostly by seventeenth- and eighteenth-century philosophers, and cryptographic and 
secret languages designed to pass messages within a group of initiates (Albani, Buonarroti 2011, p. 12-13).

Lingua ignota and Láadan, although ostensively invented for literary use, cannot be unambiguously pigeonholed as artlangs due to their social dimensions, and, since they were created in the form or neography, cannot be unambiguously described as auxlangs either. A close analysis of their origins and linguistic features will reveal their differences and, more importantly, similarities.

\section{Hildegard of Bingen and Lingua Ignota}

The urge to create languages is recorded very early in the history of humankind. In Plato's Cratylus Socrates famously ponders the exegesis of abstract terms and

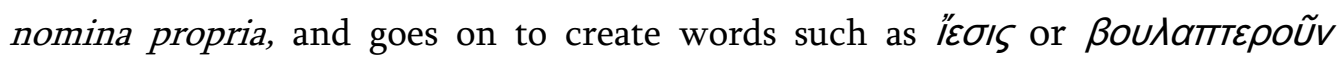
coined from existing Greek words (1903, 426c; 417e). There seem to have been languages created in ancient times, although no records of their lexis or grammar have been preserved; therefore lingua ignota created by Hildegard of Bingen, twelfth-century German abbess and polymath, is considered to be the first documented example of a constructed language (Okrent 2010, p. 10).

The language, described by Okrent as "the first published conlang" (2010, p. 291), has been preserved as glossaries listed in two codices: the Wiesebaden Codex (also referred to as Riesencodex) and the Berlin MS, and a single canticle $O$ orzchis Ecclesia. The Wiesebaden Codex contains more information on ignota lingua per simplicem hominem hildegardem prolata; theBerlin MS serves as an abbreviated version of the idea. Hildegard's neography, litterae ignotae, is included in both sources and, additionally, can be found in a handful of other manuscripts (Higley 2007, pp. 145-146). The script comprises 23 letters and is based on Latin and possibly Hebrew alphabets and can be found in various locations as a set contrasted with Latin alphabet and in inscriptions (Schnapp 1991, p. 272). The lexical resource contains 1011 words, mostly nouns and adjectives, with their equivalents in Latin and occasionally in German written above (Higley 2007, p. 151). The vocabulary is miscellaneous and divided into six (the Wiesbaden codex), or fifteen (the Berlin codex) categories: terms relating to God and religion, humans and their relationships, body parts, clothing, accommodation, household items, plants, animals, etc. (Schnapp 1991, p. 284). Lingua ignota seems centred on realistic lexis (argumzio, 'gryphon' is listed among birds as it was regarded in Middle Ages not less real than the eagle), lacking abstract nouns; the three examples of abstract concepts from O orzchis Ecclesia are all absent in lists. Although at times exhaustive (various nouns for hair types), 
the list omits many words which seem to have deserved a place among similar items (domesticated animals are absent whereas various exotic and purely imagined creature are listed). Hildegard does not shy away from lemmas considered improper for a virginal abbess: body parts, male genitalia, and excrement, the creativity which scandalised nineteenth-century German scholars (Higley 2007, p. 16).

Lexis, and possibly phonology, is based on existing languages, which does not mean it slavishly follows all features existing in the languages of inspiration; lemmas origin from Latin and Middle German, often retaining the first syllable from its source word, e.g. Luzeia, 'eye', stems from the Latin word lux - 'light' (Higley 2007, p. 148). Certain words are created stems with added prefixes, e.g. maiz - 'mother', hilz-maiz - 'stepmother'. Part of the lexis does not seem to have been inspired by any existing languages, which is a result, according to Albani and Buonarroti, of the strategy of syllabic lengthening and split diphthongs: "alcune parole sembrano assolutamente inventate, risultato di dissociazioni di dittonghi, di allungamenti sillabici, ecc.” (2011, p. 192). Schnapp claims certain lemmas origin from Greek and Hebrew (Schnapp 1991, p. 290), although Higley does not agree, likening such attributions to legends (Higley 2007, p. 26).

Only one text utilising the words from the list survives in three sources: the Wiesbaden codex and two other codices held in the Württembergische Landesbibliothek in Stuttgart and the Nationalbibliothek in Vienna. The whole canticle, or antiphon, is written mostly in Latin:

$$
\begin{gathered}
\text { O orzchis Ecclesia, } \\
\text { armis divinis praecincta, } \\
\text { et iacinto ornata, } \\
\text { tu es caldemia stigmatum loifolum } \\
\text { et urbs scienciarum. } \\
\text { O, o tu es etiam crizanta } \\
\text { in alto sono, } \\
\text { et es chorzta gemma. }
\end{gathered}
$$

(O measureless Church, girded with divine arms and adorned with jacinth, you are the fragrance of the wounds of nations and the city of sciences. $\mathrm{O}, \mathrm{o}$, and you are anointed amid noble sound, and you are a sparkling gem.).

The antiphon, or canticle, contains only one word also present in the lists, clearly pointing to a more extensive vocabulary created by Hildegard and possibly lost with the missing manuscripts. The text itself is two Latin-structured sentences with five words injected in Lingua ignota: adjectives orzchis, crizanta, and chorzta, 
and nouns caldemia and loifolum. The examples appear to utilise grammatical gender borrowed from Latin (ecclessia is feminine, and crizanta and chorzta follow the rules of the Latin first declension) and loifolum, listed in Hildegard's glossary as loifol, is Latin genitive plural. Other words, however, may have distinctively German appearance, especially with sets of consonants ending the words: suinz - 'sweat', luzerealz - 'eye socket'. While blends of consonants occur more than occasionally, there seem to be no diphthongs, and the number of vowels is limited (Schnapp 1991, p. 290). What Schnapp describes as 'clustering' (consecutive words in the list are equipped with the same syllables; 1991, p. 290) suggests the language was created as a word list and then possibly applied in texts.

Lingua Ignota has been a subject of controversy among scholars. Authorship disputes aside, Hildegard's glossopoeia has been attributed to divine inspiration (Okrent 2010, p. 11), glossolalia or a prophetic language (Schnapp 1991, p. 273), search for "a specific kind of religio-esthetic effect" (Peterson 2015, p. 7), and a purely intellectual play (Flanagan 2011, p. 20). Schnapp attributes the wide range of vocabulary associated with plants and the human body to the possible healing purpose of lingua ignota in correlation with Hildegard's medical practice applying incantations and 'verbal charms' (1991, p. 286). Higley cites "spiritual, philosophical, and aesthetic purposes" (2007, p. 11) and denies lingua ignota any functions associated with women's experience (2007, p. 9). Okrent points to the intentional character of Hildegard's work: “Though Hildegard's language may have been motivated by some kind of divine inspiration, the fact that it was written down, with the words carefully organised into meaningful categories and with some structural relationships between words indicated by endings, makes it look more like an intentional work of an inventor with a plan than the channellings of a spiritual medium" (2010, p. 11). This intentionality is supported by Bausani, who also notices another possible dimension of lingua ignota: "L'ignota lingua sembra piuttosto da riconnettere a forme di gioco sacro del tipo Eva-Ave o Sator/Arepo, con in piu, probabilmente, un reale interesse istintivo per la «invenzione linguistica». Secondo l'abbe Franche essa sarebba stata addirittura un gioco: anche se tale opinione e eccesiva, la glossolalia sembra senz'altro, per la lingua ignota, da escludarsi." (Bausani, after Albani and Bounarroti 2011, p. 192). Green, however, points to Hildegard's own words and lingua ignota'sposition within the Wiesbaden codex as a clear indication of its prophetic nature: in Hildegard's letter to Pope Anastasius, lingua ignota is accredited to divine inspiration (Green 2005, pp. 217, 220).

Flanagan does not appear as generous as other scholars, judging Hildegard's invention rather harshly: "(Lingua ignota) may have found someplace 
in the domestic economy as a secret code, if indeed there were anything more than an intellectual diversion on a level with crossword puzzles" (2006, p. 20). Rogers goes even further in expressing doubts whether the language was ever intended for any practical application or speech (2011, p. 127). Although these negative opinions are not entirely undeserved, it seems more reasonable to accept, particularly when reminded of the loss of possibly more extensive accounts of lingua ignota, that the language was consciously invented to serve multiple purposes, among which a means of communication for the monastic community of Rupertsberg cannot be excluded. The vocabulary focused instead on everyday practicalities and the reality of Church and convent life suggests its various applications to Hildegard's numerous, often scientific, interests: botany, healing, domestic economy, and religious chants. To dismiss the importance of these topics is to dismiss the validity of occupations traditionally associated with women of the Middle Ages and other times when female occupations were limited to what men found frivolous or boring.

\section{Suzette Haden Elgin and Láadan}

When Suzette Haden Elgin published the first novel in the Native Tongue series (Native Tongue, 1984; The Judas Rose, 1987; Earthsong, 1993), the idea of a language created exclusively for women had already been realised in the Nüshu script used by female residents of Hunan province in China (Endo 2001). Suzette Haden Elgin, a professor of linguistics researching tribal languages and feminism, was in a unique position to create a fully functional language which would fulfil functions other than purely aesthetic. Similarly to Tolkien's Elvish languages, Láadan is prior to the novels: Elgin confesses in the introduction to A First Dictionary and Grammar of Láadan: Second Edition that she first encountered the feminist hypothesis of the gender inadequacy of languages in 1981 and decided to construct a language to test the newly discovered issue. In 1982 she began her work on Láadan and eventually published it in the form of a science fiction novel (Elgin 2002). The result is a fully functional language with complete grammar, orthography matching its phonological features, and lexis sufficient for communication, although the novels contain but a fracture of lexis and hardly any grammatical principles are explained in the three narratives.

It is the Internet that has changed the rules of linguistic creation: many conlangers' websites and discussion boards, online dictionaries and thesauri provide invaluable insight into the community of language creators and fans. Nowadays Láadan, similarly to many other conlangs created in the twentieth century, has a website offering theoretical and practical information about 
the language, a dictionary and sample lessons, which appears to be the last attempt at popularising the language among the female world population, albeit limited to the English speaking one.

The world of the Native Tongue trilogy is linguistically stratified to illustrate the divisions in its society. Terrans, who conduct interplanetary travel and politics, speak Panglish: an international version of English which is also spoken in communication with extraterrestrial races. Aliens have their own languages, not much of which is said in the narrative. The socio-political rules of Terrans dictate a strict separation of male dominance and female servitude. With the repeal of the 19th Amendment, women are relegated to the role of wives and mothers ("to their proper and valuable place in society"; Elgin 1987, p. 49) and, when they no longer serve their childbearing purpose, they are sent away to the Barren Houses. Here Láadan is invented and developed, a language designed to enable honest and empathetic communication between women. The constructed language, dismissively named Langlish by men, is created by women previously belonging to the group of 'linguists', a genetically designed race employed to conduct communication with extraterrestrial races. The women also invent a ploy aimed to appease men alarmed by the very existence of Láadan: they present a short translation of a fragment of King James Bible in a language which is a childish simplification of Láadan. The subterfuge proves successful, and men dismiss the conlang as a silly play with which idle women amuse themselves.

Elgin's conlang is tonal in its phonology and agglutinative in its word formation, focused on pre- and suffixes modifying the meaning of coined words. One significant example of linguistic inspirations behind Láadan can be traced to Navajo: evidentials, or evidence morphemes, clarifying the speaker's source of information (Okrent 2010, pp. 246-248); their practicality is questioned by Menzies, who notices that constant recollection of one's source of opinion is virtually impossible (Menzies 2012, p. 29). Another unusual feature of Láadan is the presence of the Speech Act words which aim to make communication clearer and "more explicit" (Menzies 2012, p. 27). Both evidentials and Speech Act words are obligatory in order to prevent Láadan speakers from issuing any deceitful or untrue statements. Below are several utterances from The Judas Rose, which are left in the text without translation or explanation:

Thalehalwa! Very nice." Wilsha, dearloves. (Elgin 1987, p. 66)

Bomehelh! (Elgin 1987, p. 74)

Báanahosháanane? (Elgin 1987, p. 134)

Boóbin Na delith lethath oma Nathanan. (Elgin 1987, p. 209)

Bíidóhúuyaulbeyethhathnedebewa. (Elgin 1987, p. 301). 
The first utterance is unique since it mixes English (or Panglish, as the narrative names it) and Láadan, pointing to the newness of the conlang and its still limited use within the female community. Three utterances commence with Speech Act words and morphemes: báa- marking a question, bóo- signifying a polite request, and bii- expressing a statement. $W a$ is an evidence morpheme, glossed in the Láadan to English Dictionary as: "The reason I claim that what I'm saying is true is that I have perceived it myself" (2002). Two pronouns also appear in the sample utterances, both second person singular. $N a$ signifies a 'you' which is dear to the speaker, ne a neutral 'you'; similarly to English, neither pronoun specifies the gender of the addressee. Tellingly, wil sha, which is a greeting, can be translated as "let there be harmony" (Láadan to English Dictionary 2002), which indicates the peaceful frame of mind invoked by Láadan.

Since Láadan is a female-oriented language, for certain professions and functions the female form serves as a standard and male derivative is created by the addition of a specific suffix (Menzies 2012, p. 23). The lexis centres on emotions and uniquely female expressions, which Menzies criticises as too extensive for most learners (although English is, according to the Oxford Dictionary estimate published on oxforddictionaries.com, a language of approximately 0.75 million words and the third largest language by the number of speakers) and argues that creating a language in order to communicate feelings is counterproductive for gender tensions (Menzies 2012, p. 20). Elgin's premise, however, stems from the injustice felt by theoreticians and activists of the secondwave feminism, who distrusted the prescriptive attempts of, usually male, linguists at retaining male pronouns and appellatives as dominant in many of the Western languages. Bodine in her seminal article "Androcentrism in prescriptive grammar: singular 'they', sex-indefinite 'he', and 'he or she" claims the fight for the erasure of the singular 'they' was motivated not so much by linguistic pedantry as by androcentric attitude to grammar (1975, pp. 129-146). Although the fight was lost before it began, since most writers did not and do not follow the prohibition of singular 'they', Elgin must have despaired over the irreparable androcentrism of English and, a linguist herself, arrived at a conclusion that only a brand new language, designed by and for women, would offer a means to gender-unbiased and truthful communication.

Since the Native Tongue is a work of fiction, the constructed language embedded in its narrative is an artlang by definition. However, as Rogers emphasises, Elgin created Láadan for two reasons: to test the Sapir-Whorf hypothesis and to offer women a language which would reflect their unique perceptions (Rogers 2011, p. 120), and the linguist herself describes her creation as "a language of harmony designed to express the perceptions of women" (Elgin 
1999); therefore the right classification here is 'auxlang'. One of the several reasons for the creation of constructed languages, especially ones intended as auxiliary languages, mentioned by Adams, also fits Elgin's assumptions: political motives: "Inventing a language (...) may promote intersections of culture and ideology, or provide political or cultural voice to those silenced or inhibited by natural language (...)" (2011: chapter 1). It also serves as a counterweight to the linguistic imperialism of English and a means to fight its oppression (Mohr 2005, p. 90). It may be then asserted that Láadan spans various categories of conlangs and combines multiple purposes, not unlike lingua ignota.

\section{Conclusions}

Lingua ignota and Láadan failed as did all other conlangs (unless the severalthousand-strong Klingon fanbase is proof of its linguistic success). Did they fail because they were created for women and intended for their exclusive use? Alternatively, did they fail because, in the world experiencing the death of languages every day, there is no place for more? Individual reasons for the failure of individual languages may vary, there is nonetheless one common denominator: no language, natural or constructed, even the most beautifully designed, offers a painless path to its acquisition, hence most learners, motivated by convenience, will instead choose a language offering immediate communicative benefits to the learners rather than possible future rewards to the humankind. And since no language is ambiguity-proof, as Borges eloquently explains in his essay on the logical language of John Wilkins (1993), artificial languages do not appear worth the effort.

When the meaning of success is redefined, however, both lingua ignota and Láadan have succeeded in their various goals. Her glossopoeia offered Hildegard a means to communicate her spiritual message, whether it concerned antiphons and other religious utterances; it may also have served as a language more suited for her entirely female congregation and as an ancillary technique in her healing practice. The language is a success also as a testament to the women's linguistic creativity which blossomed in a very unusual place. It seems impossible for a man to create a language sensitive to such spiritual and mystic applications. Dismissive opinions of the glossolalic features of lingua ignota are simply unjust in the light of its uniqueness: there are no earlier or contemporary linguistic efforts with which it can be compared and even the seventeenthand eighteenth-century logical languages do not possess any superior qualities 
and, similarly to all other constructed languages, remain within the domain of an intellectual experiment.

Láadan has also succeeded in scrutinising linguistic differences between female and male perception and in emphasising the role of language in gender equality. Although Elgin's assumptions about the future of Láadan proved false, it did manage to encourage some women to discuss and even learn, in some cases at least (Okrent 2010, p. 248), grammatical features that enable more emotionally charged and thus more truthful communication. In the time of its publication, it brought a fresh view into the discussion on linguistic dimensions of feminism and patriarchy and scrutinised the liberating, self-asserting role of female-only secret languages.

Both lingua ignota and Láadan have a prominent place in the glossopoetic timeline. The former constructed to express thoughts and intuitions which Hildegard saw as impossible to convey in Latin or German. The similar desire leads John Wilkins and other philosophers to follow the glossopoetic path towards logical languages, invented solely for the purpose of unambiguous communication of ideas hopelessly lost in the chaos of their native languages. Láadan enters the stage when equal rights movements feel disillusioned and dissatisfied with androcentrism domineering their native tongues. Most tellingly, the 1980s also saw the first edition of Marc Okrand's Klingon Dictionary and the development of Klingon, which, unlike Láadan, is warfare-oriented and hence not suitable for nuanced expressions of feelings and intuitions. Nevertheless, it is Klingon that boasts a significant number of speakers, although lower than Esperantists contrary to popular belief (Okrent 2010, pp. 272-273), and is still expanding its lexical resources, whereas Láadan has descended into linguistic obscurity and is not used even by a handful of speakers. This opposition between Láadan and Klingon demarcates the differences in the realisation of what is perceived as feminine and masculine in language.

In conclusion, contrary to Higley's adverse verdict concerning the existence of "feminine aesthetic or grammar" in conlangs created by women (2007, p. 9), lingua ignota and Láadan prove gender can and does have influence on glossopoeic acts, albeit less tangible as it is enclosed in the intent of their creatresses rather than grammatical rules. How empowering is the female glossopoeia? The answer varies depending on the definition of linguistic and glossopoeic success one applies. 


\section{Bibliography}

Adams, Michael (2011). From Elvish to Klingon. Exploring Invented Languages, Oxford: Oxford University Press.

Albani, Paolo and Berlinghiero Buonarroti (2011). Aga magéra difúra. Dizionario delle lingue immaginarie, Bologna: Zanichelli.

Barnes, Lawrie and Chantelle van Heerden. (2006). Virtual Languages in Science Fiction and Fantasy Literature. Language Matters: Studies in the Languages of Africa, vol. 37. London: Routledge.

Bodine, A. (1975). 'Androcentrism in prescriptive grammar: singular "they", sex-indefinite "he", and "he or she.", Language in Society, 4 (02), pp. 129-146.

Borges, Jorge Luis (1993). 'The Analytical Language of John Wilkins', Other inquisitions 1937-1952, Austin: University of Texas Press, 1993. [Accessed 20 January 2019], http://www.alamut.com/subj/artiface/language/johnWilkins.html.

Conley, Tim and Stephen Cain (2006). Encyclopedia of Fictional and Fantastic_Languages, Westport, London: Greenwood Press.

Eco, Umberto (1995). The Search for the Perfect Language, Oxford: Blackwell Publishers Ltd.

Elgin, Suzette Haden (1987). The Judas Rose, New York: Daw Books.

Elgin, Suzette Haden (1999). 'Interview with Kim Wells', Women Writers: A Zine. [Accessed 21 May 2017]: http://www.womenwriters.net/editorials/hadenelgin.htm.

Elgin, Suzette Haden (2002). 'Introduction. The Construction of Láadan', Láadan Language. [Accessed 20 January 2019]: https://laadanlanguage.wordpress.com/articles/articlesby-suzette/about-laadan/.

Endo, Orie (2001). World of Nushu, webpage. [Accessed 20 January 2019]: http://nushu.world.coocan.jp/home.htm.

Flanagan, Sabina (2006). Hildegard of Bingen: A Visionary Life, New York: Routledge.

Green, Jonathan P. (2005). 'A New Gloss on Hildegard of Bingen's Lingua Ignota', Viator, 36: 217-234.

Higley, Sarah L. (2007). Hildegard of Bingen's Unknown Language. An Edition, Translation and Discussion, New York: Palgrave MacMillan.

Láadan to English Dictionary (2002). [Accessed 20 January 2019].

Menzies, Ruth (2012). 'Creating a 'Truer' Language Within a Work of Fiction: The Example of Suzette Haden Elgin's Native Tongue', E-rea [En ligne], 9.2. [Accessed 20 January 2019]: https://erea.revues.org/2410\#quotation.

Mohr, Dunja M. (2005). 'Worlds Apart?: Dualism and Transgression in Contemporary Female Dystopias', in Donald E. Palumbo, C.W. Sullivan III (eds) Critical Explorations in Science Fiction and Fantasy, vol. 1. Jefferson: McFarland, Inc.

Okrent, Arika (2010). In the Land of Invented Languages: Adventures in Linguistic Creativity, Madness, and Genius, New York: The Random House Publishing Group.

Peterson, David J. (2015). The Art of Language Invention: From Horse-Lords to Dark Elves, the Words Behind World-Building, New York: Penguin Random House LLC. 
Plato (1903). Cratylus, [in:] Platonis Opera, John Burnet (ed.), Oxford: Oxford University Press.

Rogers, Stephen D. (2011). A Dictionary of Made-up Languages. From Adûnaic to Elvish, Zaum to Klingon - The Anwa (Real) Origins of Invented Lexicons, Avon: $\mathrm{F}+\mathrm{W}$ Media, Inc.

Schnapp, Jeffrey T. (1991). 'Virgin Words: Hildegard of Bingen's Lingua ignota and the Development of Imaginary Languages Ancient to Modern', Exemplaria, 3:2, 267298. [Accessed 20 January 2019]: http://www.tandfonline.com/doi/abs/ $10.1179 / 104125791790511223$.

Stockwell Peter. (2006). 'Invented Language in Literature', in Keith Brown et al. (eds) Encyclopedia of Language \& Linguistics, vol. 6, pp. 3-10, Amsterdam: Elsevier Science.

Wojan, Katarzyna (2016). 'Języki skonstruowane jako obiekt badań współczesnej interlingwistyki', Biuletyn Polskiego Towarzystwa Językoznawczego, LXXII, pp. 121-136.

Yaguello, Marina (1991). Lunatic Lovers of Language: Imaginary Languages and Their Inventors, London: Athlone Press. 